(An ISO 3297: 2007 Certified Organization)

Vol. 4, I ssue 1, J anuary 2015

\title{
Time of Single Stage Boost Inverter with Coupled Inductor Fed by a Fuel Cell
}

\author{
Dr.M.Balasubba Reddy \\ Professor, Department of Electrical \& Electronics Engineering, S.V.College of Engineering, Tirupathi, A.P, India
}

\begin{abstract}
The global energy consumption is increasing and the significance of a distributed generation (DG) units which includes renewable energy sources is gaining more importance. These DG units face problems like wide variation in voltages produced by renewable energy sources. For example, wind power generation is high only when the velocity of the wind is high, but this may not happen all the time. So the input will not be stable, in such situations in order to produce a stable, stepped up ac voltage with high reliability, high boost gain, this paper suggest the a single stage boost inverter with a unique impedance network including coupled inductor .By controlling the forbidden shoot through zero state and the proper design of coupled inductor this can be achieved. A fuel cell model for the converter and fuzzy control of shoot through zero state is presented in paper.
\end{abstract}

KEYWORDS: Fuzzy logic controller, Proton exchange membrane (PEM) fuel cell, Single stage, Shoot through zero state

\section{INTRODUCTION}

High consumption of major energy source and noticeable environmental pollution led to great opportunity for DG units using renewable energy sources like wind turbines, photovoltaic (PV) generators, fuel cells, small hydro systems[1]. One of the major problems associated with this is wide range of voltage variation due to the fluctuation in energy source impose stringent requirements for the inverter topologies and controls [2]. Normally, a boost type dc to dc converter can be added to step up the voltage. Although it is a simple topology, it may not be able to produce enough voltage gain when the input is very low, even with extreme duty cycle. Also, large duty cycle operation may result in serious reverse-recovery problems and increase the ratings of switching devices. The boost converter increases the overall size and weight of the system. In conventional voltage source inverter upper and lower switches of same leg cannot be gated on at the same time because it can cause device failure and shoot-through problems. In order to avoid shoot through problems dead time is always used, but it will cause waveform distortion [3]. So it is desirable to use a single stage boost inverter with no shoot-through issues.

Single stages topologies are the focus of research now days, in this topology the performance of each stages in a multistage converter are integrated. This reduces the size and cost of the system and also the efficiency and reliability are increased. On the other hand, the control complexity is high in these types of topologies.

This paper presents a novel single stage boost inverter with coupled inductor fed by a fuel cell. Here the input given can be a variable source. The bus voltage can be boosted by utilizing shoot-through zero state to store energy and transfer it within the impedance network. This inverter completely avoids destroying the devices during shootthrough. The shoot-through zero states and coupled inductor's turn ratio are regulated to control the boost gain. Thus the output voltage can be regulated in wide range. 


\title{
International Journal of Innovative Research in Science, Engineering and Technology
}

(An ISO 3297: 2007 Certified Organization)

\author{
Vol. 4, I ssue 1, J anuary 2015
}

\section{PROPOSED TOPOLOGY}

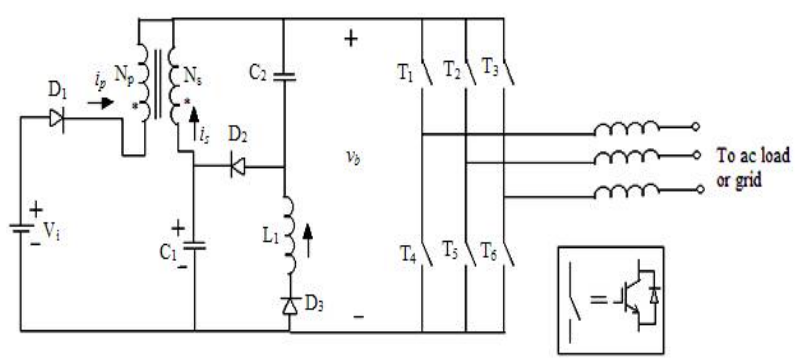

Fig.1 Proposed converter

It provides a unique impedance network to combine the three-phase inverter bridge with the source. The impedance network does not use any switching devices and this may lead to improved reliability, higher efficiency, and lower cost. Operation range of the inverter can be extended by using a coupled inductor with a low leakage inductance. This converter is suitable for outputting a stable ac voltage where the input voltage varies from a relative low level to a higher level continuously. The dc source can be a battery, diode rectifier, fuel cell, or PV cell.

To describe the operating principle and characteristics, this paper focuses on one application example of the singlestage boost inverter: a single-stage boost inverter for fuel cell. Fuel cells produce a voltage that changes widely depending on current drawn from the stacks. For fuel-cell vehicles and distributed power generation, a boost dc-dc converter is required because the voltage source inverter cannot produce an ac voltage that is greater than the dc voltage. Single stages boost inverter shown in Fig.1can used for fuel-cell applications, which can directly produce an ac voltage greater and less than the fuel-cell voltage with single stage operation.

\section{OPERATING PRINCIPLE AND ANALYSIS OF BOOST CHARACTERISTICS}

Conventional VSI has eight possible switching states, in which two are zero states and remaining six are active states. Two zero states are indicated by turning on upper or lower three devices, which make the load terminals shorted through. Six active states are indicated by turning on the switches from different phase legs, when the input dc voltage is applied across the load. However, a three-phase single-stage boost inverter has one extra zero state when the load terminals are shorted through both the upper and lower devices. For distinguishing between the zero states mentioned earlier, the two zero states named as open-zero state and the extra zero state as shoot-through zero state. Shootthrough zero state is forbidden in the conventional VSI because it would cause device failure. By combining the impedance network with the three-phase bridge, the shoot-through zero state provides the unique boost feature to the inverter. It should be noted that shoot-through zero states are allocated into open-zero states without changing the total open-zero state time intervals. So the active states are unchanged. Thus, the shoot-through zero state does not affect the pulse width modulation control of the inverter, because it equivalently produces the same zero voltage as the open-zero state to the load terminal. Single stage boost inverter works under three different switching states [4].
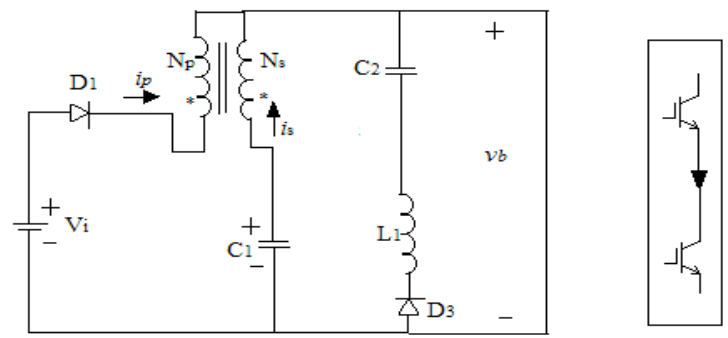

Fig.2 Shoot through zero state 


\section{International Journal of Innovative Research in Science, Engineering and Technology}

(An ISO 3297: 2007 Certified Organization)

\section{Vol. 4, I ssue 1, J anuary 2015}

Switching state 1: Fig.2 shows that the converter is in shoot-through zero state. Bus voltage $v b$ was shorted to ground and diode $\mathrm{D}_{2}$ is reverse biased. When input dc voltage is applied across primary winding of the coupled inductor, primary current increase linearly. The inductive voltage of secondary winding charges $\mathrm{C}_{1}$, while $\mathrm{C}_{2}$ is discharged by $\mathrm{L}_{1}$ with linearly increasing current, assuming that the capacitor voltage is constant.

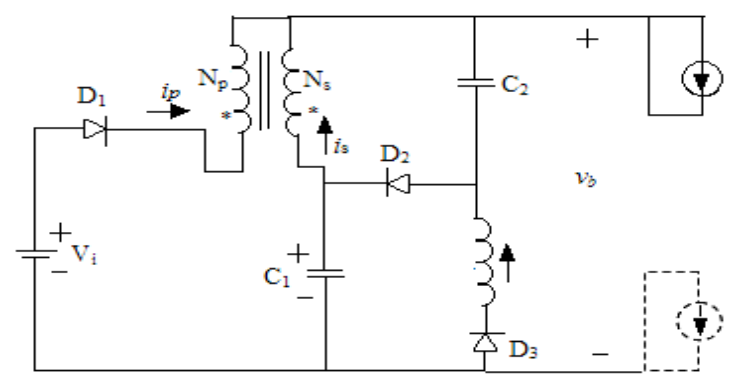

Fig.3 Open zero state

Switching state 2: Fig. 3 shows the converter is in open-zero states. Inductor $\mathrm{L}_{1}$ charge capacitors $\mathrm{C}_{1}$ and secondary winding of the coupled inductor charge $\mathrm{C}_{2}$ through diode $\mathrm{D}_{2}$. In this state, the current of inductor $\mathrm{L}_{1}$ decreases from peak value to zero.

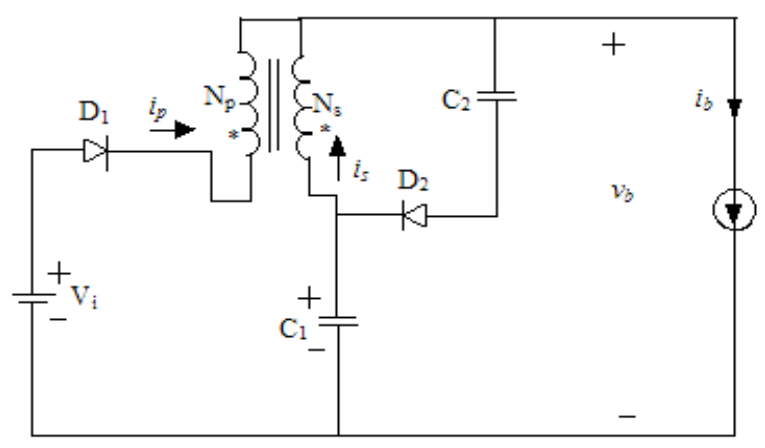

Fig.4 Active state

Switching state 3: When the circuit is in one of the six active states, diode D3 is reverse biased as shown in Fig.4. The energy stored in the coupled inductor and $\mathrm{C}_{1}$ releases to the load, and the bus voltage is boosted to a higher level. Lower and higher boost gain modes can be achieved by regulating the shoot through zero state as well as configuring the turn ratio and coupling coefficient of the coupled inductor. In lower voltage boost 


\section{International Journal of Innovative Research in Science, Engineering and Technology}

(An ISO 3297: 2007 Certified Organization)

\section{Vol. 4, I ssue 1, J anuary 2015}

gain applications, the key characteristic is that the current through $L_{p}$ generally works in continuous mode. The boost gain is similar to conventional dc to dc boost converter.

In higher voltage boost gain applications, the key characteristic is that the inductance of primary winding is less than that of secondary winding, and primary winding current generally works in discontinuous mode.

Define the coupling coefficient as

$\mathrm{k}=\mathrm{M} /(\mathrm{Lp} \times \mathrm{Ls})^{1 / 2}$

where $\mathrm{Lp}$, Ls, and $\mathrm{M}$ are the self-inductance of each winding and the mutual inductance, and the effective turn ratio.

$\mathrm{N}_{\mathrm{e}}=\left(\mathrm{L}_{\mathrm{S}} / \mathrm{L}_{\mathrm{p}}\right)^{1 / 2}$

Define the duty cycle $\mathrm{D}_{1}$ as the time when the inductor $\mathrm{L}_{\mathrm{p}}$ current decreasing from peak value to zero, the average voltage across the both sides of coupled inductor during one shoot-through period can be expressed as

$\left(\mathrm{V}_{\mathrm{Lp}}(\mathrm{t})\right) \mathrm{Tsh}_{\mathrm{s}}=\mathrm{D}_{0} \mathrm{~V}_{\mathrm{i}}+\mathrm{D}_{1}\left(\mathrm{~V}_{\mathrm{i}}-\mathrm{V}_{\mathrm{b}}\right)+\left(1-\mathrm{D}_{0}-\mathrm{D}_{1}\right) \mathrm{k}\left(\mathrm{V}_{\mathrm{c}}-\mathrm{V}_{\mathrm{b}}\right) / \mathrm{N}_{\mathrm{e}}$

$\left(\mathrm{V}_{\mathrm{Ls}}(\mathrm{t})\right) \mathrm{Tsh}_{\mathrm{sh}}=\mathrm{D}_{0} \mathrm{~V}_{\mathrm{c} 1}+\left(1-\mathrm{D}_{0}\right)\left(\mathrm{V}_{\mathrm{c} 1}-\mathrm{V}_{\mathrm{b}}\right)=0$

Define physical turns ratio of ideal transformer as $\mathrm{N}=\mathrm{N}_{\mathrm{S}} / \mathrm{N}_{\mathrm{p}}$. According to the relationship of $\mathrm{N}_{\mathrm{e}}$ and $\mathrm{N}, \mathrm{N}_{\mathrm{e}}=\mathrm{N} \times \mathrm{k}$, (3) and

(4) can be simplified as

$\mathrm{B}=\mathrm{V}_{\mathrm{b}} / \mathrm{V}_{\mathrm{i}}=\left(\mathrm{D}_{0}+\mathrm{D}_{1}\right) \mathrm{N} / \mathrm{D}_{1} \mathrm{~N}+\left(1-\mathrm{D}_{0}-\mathrm{D}_{1}\right)$

The output peak phase voltage $V_{\text {ac }}$ generated by the inverter can be expressed as

$\mathrm{V}_{\mathrm{ac}}=\mathrm{mBV} \mathrm{i} / 2$

The output ac voltage can be stepped up or stepped down by selecting appropriate voltage gain $\mathrm{G}$, where $\mathrm{G}$ is

$\mathrm{G}=\mathrm{m} \times \mathrm{B}$

From (7), voltage gain depends on modulation index and boost gain. By regulating $G$ the output ac voltage can be changed in wide range. According to (5), boost gain B is depend on shoot through duty ratio $\mathrm{D}_{0}$, duty cycle $\mathrm{D}_{1}$, and physical turns ratio $\mathrm{N}$ of coupled inductor. The available shoot-through duty cycle is limited by the traditional openzero duty cycle which is determined by the modulation index $\mathrm{m}$.

The capacitor voltage $\mathrm{C}_{1}$ and $\mathrm{C}_{2}$ voltage can be expressed as $\mathrm{V}_{\mathrm{c} 1}=\mathrm{V}_{\mathrm{b}} \times\left(1-\mathrm{D}_{0}\right)$

(8) $\mathrm{V}_{\mathrm{c} 2}=\mathrm{V}_{\mathrm{b}} \times \mathrm{D}_{0}$

Duty cycle $\mathrm{D}_{1}$ can be expressed as

$\mathrm{D}_{1}=\left[\mathrm{NV}_{\mathrm{i}}-\left(1-\mathrm{D}_{0}\right) \mathrm{V}_{\mathrm{b}}\right] \mathrm{D}_{0} /\left(\mathrm{N}-\mathrm{D}_{0}\right) \mathrm{V}_{\mathrm{b}}-\mathrm{NV}_{\mathrm{i}}$

Two investigations can be found from (10).First, for given boost gain and shoot through for a larger turns ratio or lower coupling coefficient can induce larger duty ratio D1, which means larger leakage energy to take more time to release.Second, when turns ratio and coupling coefficient are fixed for a lower boost gain and larger shoot through duty ratio $\mathrm{D} 1$ will be high. 


\section{International Journal of Innovative Research in Science, Engineering and Technology}

(An ISO 3297: 2007 Certified Organization)

Vol. 4, I ssue 1, J anuary 2015

IV. PWM TECHNIQUE USED

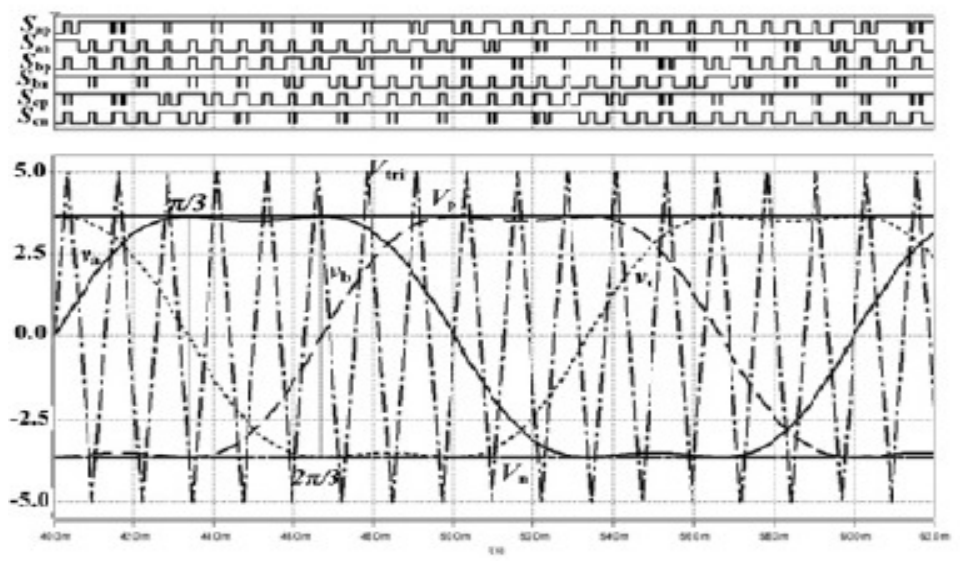

Fig.5 Maximum constant boost control method

For single stage boost inverter, maximum constant boost with third harmonic injection is used [5]. As shown in Fig.2, two straight lines $\mathrm{Vp}$ and $\mathrm{Vn}$ are used to regulate shoot trough duty cycle. When the carrier waveform is higher than the upper straight line or lower straight line, shoot through zero state are allocated into open zero state. Shooting through three phase legs at the same time can reduce the current stress of each power device, while the switching frequency is doubled. By having same time duration of shoot through zero state in every switching cycle will minimize the size of impedance network. When the modulation index $\mathrm{m}$ is set, shoot through duty ratio D0 against modulation index $\mathrm{m}$ can be expressed as

$\mathrm{D}_{0}=1-\sqrt{ } 3 \mathrm{~m} / 2$

So the maximum shoot through duty ratio is limited by modulation index.

\section{V.COUPLED INDUCTOR DESIGN}

Coupled inductor can be modeled as a magnetizing inductor, an ideal transformer with a turns ratio of $\mathrm{N}$ and a leakage inductor as shown in Fig. 3 where $\left(1-\mathrm{k}^{2}\right) \mathrm{L}$ and $\mathrm{k}^{2} \mathrm{~L}$ are commonly referred to the leakage inductance and magnetizing inductance respectively.

The transformer model of coupled inductor [6] can be expressed as $\mathrm{V}_{\mathrm{p}}-\mathrm{kV} \mathrm{V}_{\mathrm{S}} / \mathrm{Ne}_{\mathrm{e}}=\left(1-\mathrm{k}^{2}\right) \mathrm{Ldip} / \mathrm{dt}$

(12) $\mathrm{V}_{\mathrm{S}}-\mathrm{kV}_{\mathrm{S}} \mathrm{N}_{\mathrm{e}}=\left(\mathrm{N}_{\mathrm{e}}\right)^{2}\left(1-\mathrm{k}^{2}\right) \mathrm{Ldi}_{\mathrm{S}} / \mathrm{dt}$

If the relationship between primary voltage $\mathrm{V}_{\mathrm{p}}$ and secondary voltage $\mathrm{V}_{\mathrm{S}}$ can be found in different time intervals during one shoot through period $\mathrm{T}_{\mathrm{sh}},(12)$ and (13) can be expressed as

$\mathrm{V}_{\mathrm{p}}=$ Leq-pdip/dt

$\mathrm{V}_{\mathrm{s}}=\mathrm{Leq}_{\mathrm{s}} \mathrm{di}_{\mathrm{S}} / \mathrm{dt}$ 


\section{International Journal of Innovative Research in Science, Engineering and Technology}

(An ISO 3297: 2007 Certified Organization)

Vol. 4, I ssue 1, J anuary 2015

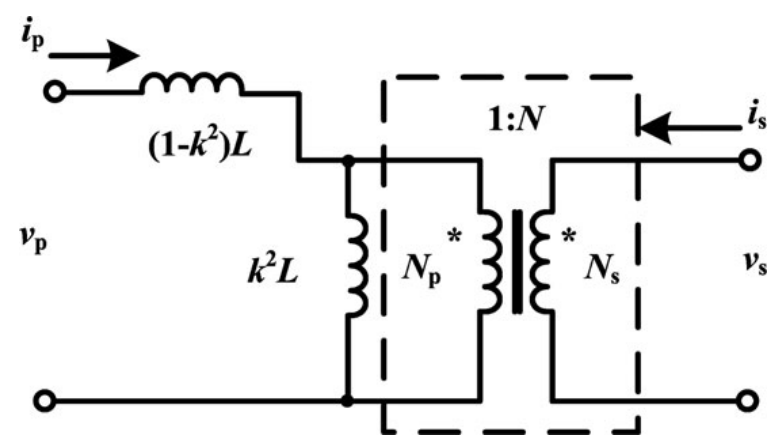

Fig.6 Equivalent circuit model of coupled inductor

where Leq-p and Leq-s are equivalent inductances of the coupled inductor at different time intervals, which is the same format as the non-coupling inductor. The relationship between $V_{p}$ and $V_{S}$ changes at different time intervals during one shoot through period. The primary equivalent inductance Leq0-p, of shoot through period $\mathrm{T}_{0}$ period can be expressed as

Leq0-p= $\left(1-\mathrm{k}^{2}\right) \mathrm{L} / 1-\left(\left(\left(1-\mathrm{D}_{0}\right)\left(\mathrm{D}_{0}+\mathrm{D} 1\right)\right) /\left(\mathrm{D} 1 \mathrm{~N}+\mathrm{D} 0\left(1-\mathrm{D}_{0}-\mathrm{D}_{1}\right)\right)\right)$

According to the desired current ripple $\Delta \mathrm{I}_{\mathrm{p}}$ of primary winding in $\mathrm{T}_{0}$, the primary equivalent inductance during the shoot through zero state can be expressed as

Leq0-p=ViD $0 T_{\mathrm{sh}} / \Delta \mathrm{I}_{\mathrm{p}}$

According to (16), the primary inductance $\mathrm{Lp}_{\mathrm{p}}$ or $\mathrm{L}$ can be obtained from the relationship between primary equivalent inductance and actual primary winding inductance in one shoot through zero state. The secondary winding inductance can also be found according to (2).

\section{CONTROL OF SHOOT THROUGH TIME}

If the input dc voltage is varying in wide range the output ac voltage can be maintained constant by controlling shoot through duty ratio. By controlling shoot through duty cycle bus voltage can regulated and according to (11) D1 only varies with input voltage $\mathrm{V}_{\mathrm{i}}$ when bus voltage preset. So a fuzzy logic controller is introduced for controlling shoot through time. 


\section{International Journal of Innovative Research in Science, Engineering and Technology}

(An ISO 3297: 2007 Certified Organization)

Vol. 4, I ssue 1, J anuary 2015

Unlike classical control strategy, which is a point-to-point control, fuzzy logic control is a range to point or range to range control. The output of a fuzzy controller is derived from fuzzifications of both inputs and outputs using the associated membership functions. To implement fuzzy logic technique to a real application requires the following three steps:

1. Fuzzification - convert classical data or crisp data into fuzzy data or Membership Functions (MFs)

2. Fuzzy Inference Process - combine membership functions with the control rules to derive the fuzzy output

3. Defuzzification - use different methods to calculate each associated output and put them into a table: the lookup table. Pick up the output from the lookup table based on the current input during an application.

For shoot through control input membership function is defined by range of error. Output membership function is defined by the range of constant values which is compared carrier wave to create shoot through pulses. So, by mapping of corresponding input and output membership function, shoot through duty ratio will be controlled according to the input variations.

\section{FUEL CELL}

Fuel cells are electrochemical devices that convert chemical energy of a fuel directly to electric energy, with no internal moving parts. The fuel cell used for modeling is Proton exchange membrane fuel cell (PEMFC).It is fed with hydrogen and air.

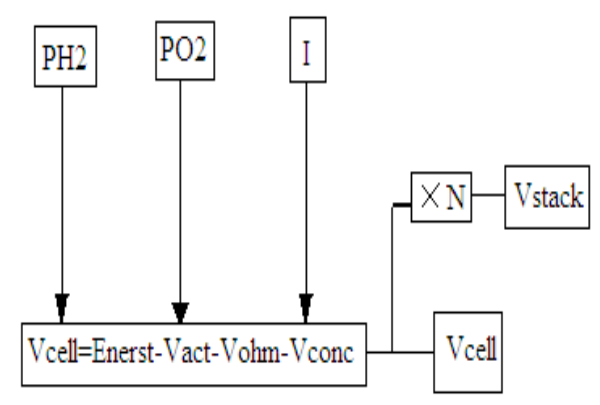

Fig.7 Static model of fuel cell

The modeling of the proton exchange membrane fuel cell is based upon the following design equations, $\mathrm{V}_{\mathrm{fc}}=\mathrm{E}$ Nernst $\mathrm{V}_{\text {act }}-\mathrm{V}_{\mathrm{ohm}}-\mathrm{V}_{\text {con }}$

Here $V_{f c}$ represents the fuel cell voltage $(V)$, ENernst represents the Nernst voltage (V), $V_{\text {act }}$ represents voltage drop due to activation of anode and cathode $(\mathrm{V}), \mathrm{V}_{\mathrm{ohm}}$ represents ohmic voltage drop (V) and $\mathrm{V}_{\text {con }}$ represents concentration or mass transport voltage drop (V).Parameters of SR-12 modular PEM generator is used for the simulation [7]. 


\section{International Journal of Innovative Research in Science, Engineering and Technology}

(An ISO 3297: 2007 Certified Organization)

Vol. 4, I ssue 1, J anuary 2015

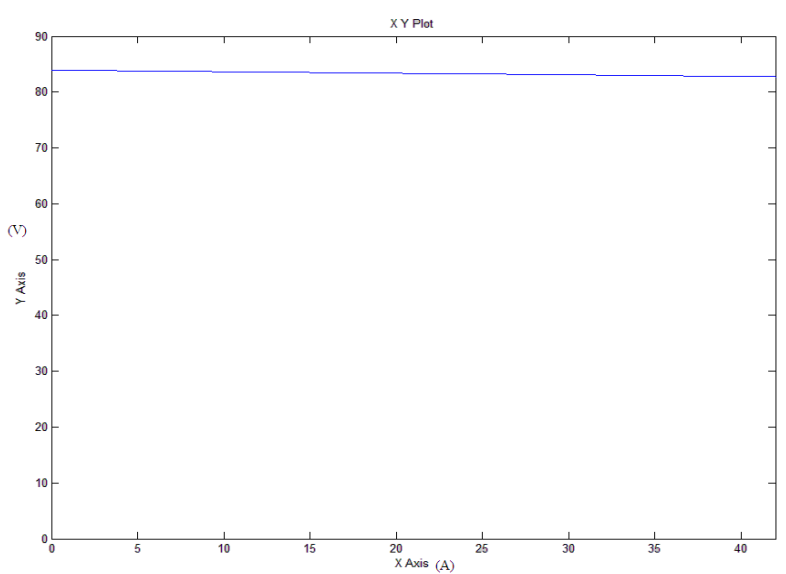

Fig.8 V-I characteristics of single FC stack

Fig.9 shows the V-I characteristics of single FC stcak.By using parameters of SR-12 PEMFC single FC stack produces around $85 \mathrm{~V}$.

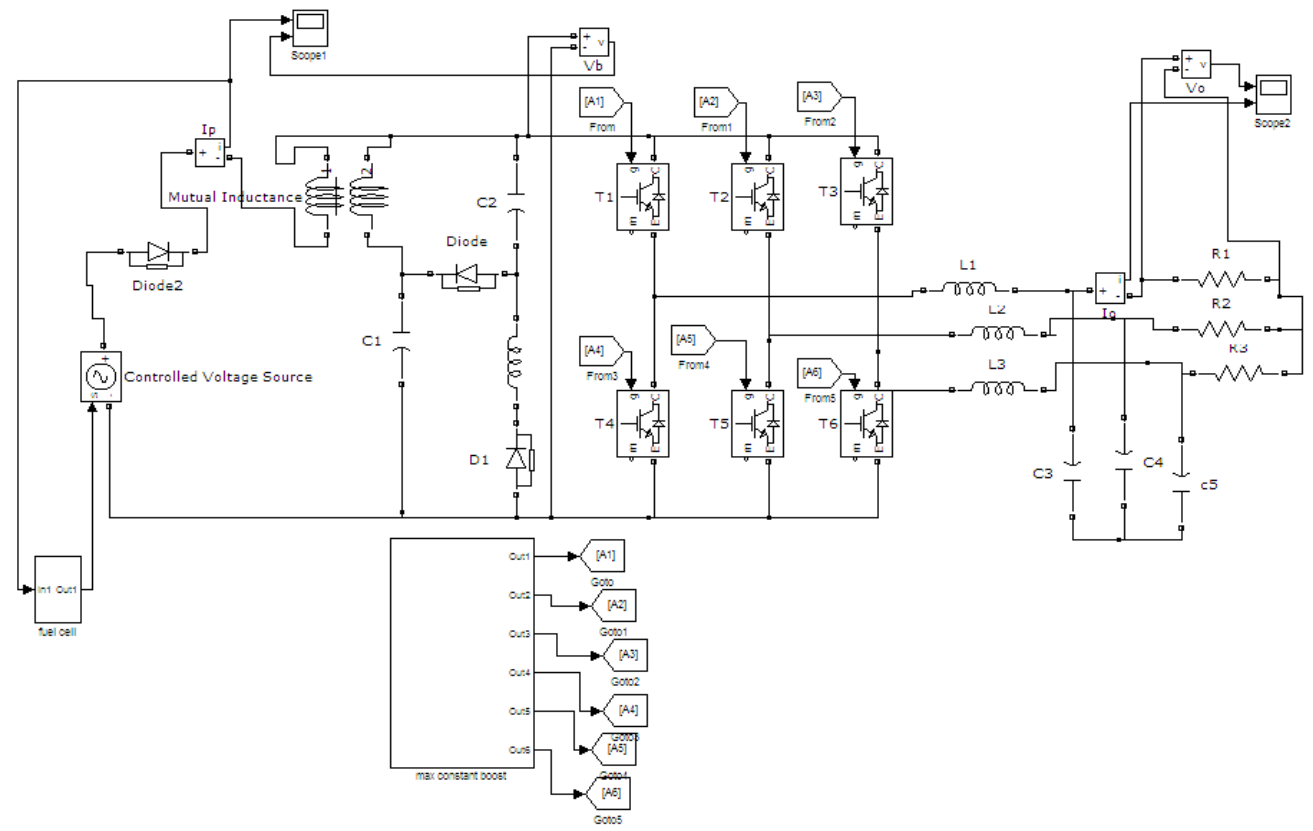

Fig.9 Simulation model of single stage boost inverter fed by a fuel cell

\section{SIMULATION RESULTS}

To verify the previous analysis simulation has been performed. The circuit parameters are $\mathrm{V}_{\mathrm{i}}=170 \mathrm{~V}, \mathrm{k}=0.98, \mathrm{~N}=2.5$, $\mathrm{Lp}=215 \mu \mathrm{H}, \mathrm{Ls}=1.87 \mathrm{mH}, \mathrm{C}_{1}=10 \mu \mathrm{F}, \mathrm{C}_{2}=100 \mu \mathrm{F}, \mathrm{L}_{1}=25 \mu \mathrm{HIn}$ this case, the modulation index was set to 0.8 and the shoot-through duty cycle was set to .18 and switching frequency was $10 \mathrm{kHz}$. The shoot-through zero state was populated in every traditional open zero state, achieving an equivalent switching frequency of $20 \mathrm{kHz}$ viewed from the impedance network. From the above analysis, we have the following theoretical calculations: 


\section{International Journal of Innovative Research in Science, Engineering and Technology}

(An ISO 3297: 2007 Certified Organization)

Vol. 4, I ssue 1, J anuary 2015

Equation (15) is the phase peak voltage, which implies that the line-to-line voltage is $190 \mathrm{~V}_{\mathrm{rms}}$ or $268 \mathrm{~V}_{\text {peak}}$. The above theoretical values are similar with the simulation results. Total harmonic distortion of output voltage is $1.51 \%$.
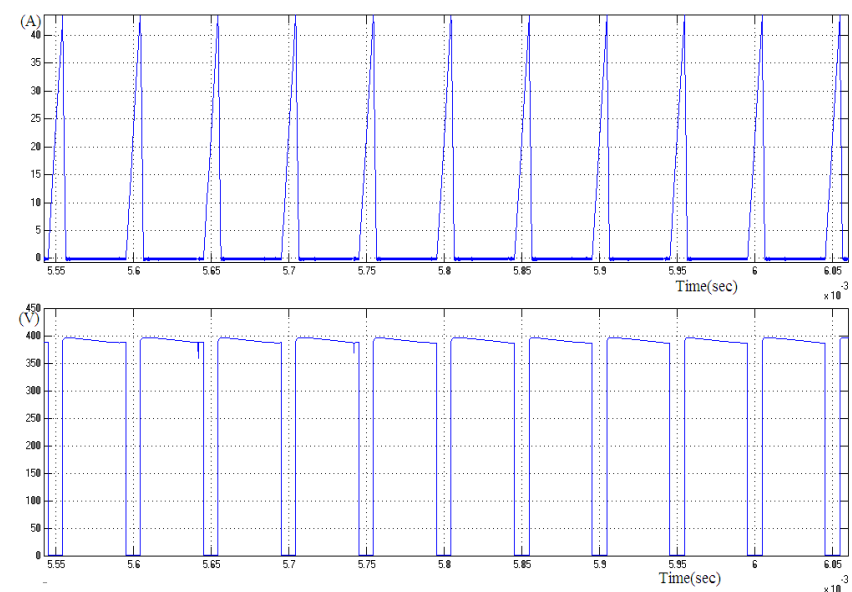

Fig.10 Primary winding current and bus voltage waveform

Fig.10 shows that the bus voltage is stepped up to $400 \mathrm{~V}$, indicating boost inverting operation of the converter.
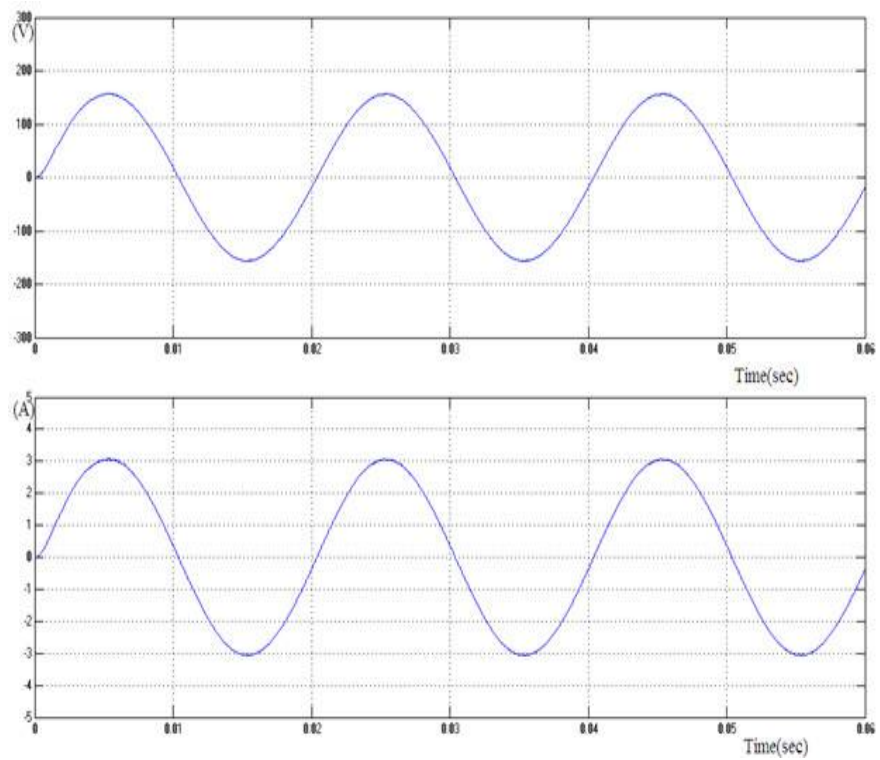

Fig.11 Output voltage and current waveform

Fig.11 shows that an output voltage of $110 \mathrm{~V}_{\text {rms }}$ is produced when the input voltage of $170 \mathrm{~V}$ is applied. 


\section{International Journal of Innovative Research in Science, Engineering and Technology}

(An ISO 3297: 2007 Certified Organization)

Vol. 4, I ssue 1, J anuary 2015
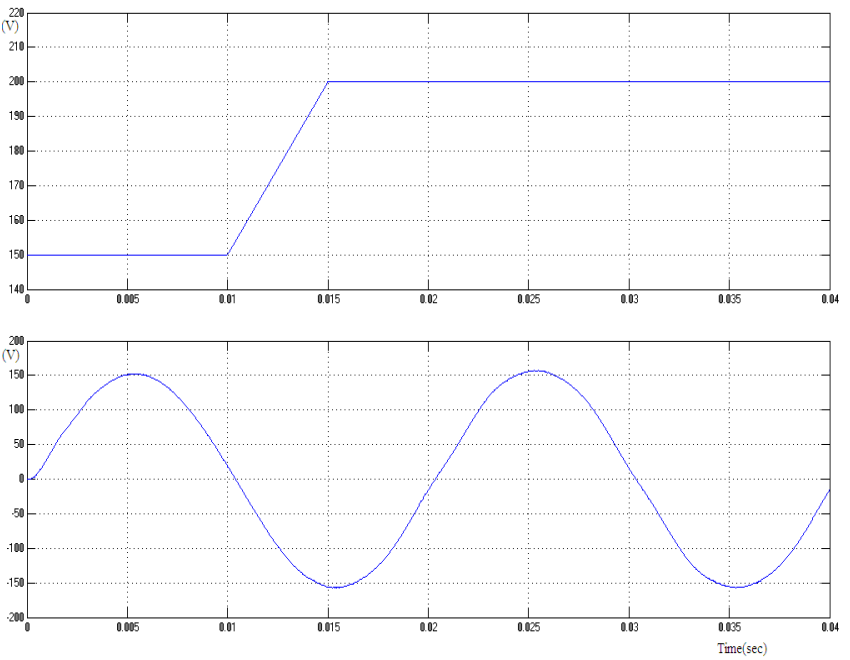

Fig.12 Variable DC input voltage and output voltage waveform

Fig. 12 shows even if the voltage varies from 150 to $200 \mathrm{~V}$, the output remains $110 \mathrm{~V}_{\mathrm{rms}}$.

\section{CONCLUSION}

This paper presents single stage boost inverter fed by a PEM fuel cell. By controlling shoot through duty ratio and proper design of coupled inductor the bus voltage can be boosted. It avoids destroying switches during shoot through .So higher reliability. The inductors and capacitors used in the network need not be highly consistent, leading to easier circuit parameters design. By controlling shoot through time even if the input transients occurs output phase voltage remains same.

\section{REFERENCES}

[1] W. T. Franke, M. Mohr, B. Wittig, and F. W. Fuchs, "Converter systems for fuel cells in the medium power range-a comparative study," IEEE Trans. Ind. Electron., vol. 57, no. 6, pp. 2024-2032, Jan. 2010.

[2] B. Kroposki, R. Deblasio, C. Pink, H. Thomas, M. Simoes, and P. K. Sen, "Benefits of power electronic interfaces for distributed energy systems," IEEE Trans. Energy Convers., vol. 25, no. 3, pp. 901-908, Sep. 2010.

[3] J.-M. Kim and S.-H.Hwang,"Dead time compensation method for voltage-fed PWMinverter," IEEE Trans. Energy Convers., vol. 25, no. 1 , pp. $1-10$, Sep. 2010.

[4] Wenxin Huang and Yufei Zhou,"Single-Stage Boost Inverter With Coupled Inductor" IEEE Transactions On Power Electronics, Vol. 27, No. 4, April 2012.

[5] J. Wang, A. Joseph, M. Shen and F. Z. Peng, "Constant boost control of the z-source inverter to minimize current ripple and voltage stress," IEEE Trans. Ind. Electron., vol. 42, no. 3, pp. 770-778, May/Jun. 2006.

[6] K.Wang and G.Zhu, "Modeling and design considerations of coupled inductor converters," in Proc. IEEE Appl. Power Electron. Conf., 2010,pp. 7-13.

[7] Felix A. Farret, Jeferson M. Corrêa, Marcelo G. Simões and Luciane N. Canha “An Electrochemical-Based Fuel-Cell Model Suitable for Electrical Engineering Automation Approach,” IEEE Trans. Ind. Electron., vol. 51, no. 5, pp. 1103-1112, Oct. 2004.

[8] Raghavendra H S and Nagaraj A M, "Snubberless Current Fed Half Bridge Isolated Converter For Fuel Cell Applications" International Journal of Electrical Engineering \& Technology (IJEET), Volume 5, Issue 8, 2014, pp. 174 - 181, ISSN Print : 0976-6545, ISSN Online: 09766553 . 